\title{
Does consultancy research have a future?
}

\section{David Streatfield}

\section{Introduction}

Ten years ago I attended a researcher briefing session organised by the British Library Research and Information Centre, the main LIS research funding body at the time. One of the participants asked whether the British Library (BL) ever awarded research grants to private companies (rather than to academic institutions and research centres). The BL spokesperson said that he couldn't recall this ever happening, but that, in principle, he could see no reason why it shouldn't. This came as a bit of a surprise since I was receiving a significant grant at that time and he was my BL contact for the work!

There is nothing unusual about consultancy researchers being the invisible players in the LIS research sandpit. A check through the indices of the volumes of British Library and Information Work from 1991 to 2005 for 'consultants', 'consultancy' and 'management consultants' revealed - nothing. This is slightly misleading because there are passing mentions in the research chapters of these and earlier volumes extending coverage back to 1966, amounting to a total of about one page. What can we learn from this round-up of the history of consultancy research?

\section{Thirty years of consultancy research}

Research consultancy in the early 1970s was conducted largely in research centres, notably Aslib and the Library Management Research Unit (LMRU) at Cambridge (later in the decade the LMRU transferred to Loughborough University of Technology and metamorphosed into the Centre for Library and Information Management, with a remit that included consultancy).

It was reported that

Aslib's Research and Development Department, first under B. C. Vickery and then under J. Martyn, has continued to involve itself in a wide range of activities of interest to the practising librarian and information scientist and thus to form a corpus of knowledge and advice on research, its background and its consequences.

\section{Author}

David Streatfield is Principal of Information Management Associates, a research, training and consultancy team operating in the public sector. He has been a recipient of national LIS research funding more or less continuously since 1975 and as a consultancy researcher since 1991.

Email: Streatfield@,blueyonder.co.uk 
(Yelland, 1977, 125)

By the end of the 1970s, the Aslib service had been repackaged as its Research and Consultancy Division, which was established "to ensure that adequate research effort is applied to practical problems." (Yelland, 1982) Both of these centres were partially supported financially by the British Library Research and Development Department and this policy was extended in this period, notably through the creation of the Centre for Research on User Studies (CRUS) at Sheffield University. However, there was a reversal in this funding strategy during the following decade, leading to the withdrawal of Aslib from research and consultancy in 1985 and the absorption of CRUS (as the Consultancy and Research Unit) into the Sheffield University Department of Information Studies in the same year.

The consultancy landscape was changing in other ways too; according to Nick Moore:

Whereas in 1981 there were a mere handful of research consultants operating in Britain, by 1985 the number had risen to over 50 and seemed set to continue. In part the increase in the number of research consultants is a reflection of the increasing tendency to take early retirement ... a significant proportion of such ventures is short-lived ... There is, however, a growing number of individuals, partnerships and consultancy firms with established reputations and a significant body of concrete results behind them.

(Moore, 1988, 277-278)

He went on to suggest that such consultancies were useful in conducting short, sharp projects focussed on particular topics.

This pattern continued for the remainder of the decade, as noted by Stephen Roberts:

In the late 1980s, independent consultants have been prominent in investigation activities, continuing an established trend in the British scene. Bodies like Capital Planning Information and the Policy Studies Institute have the infrastructure and motivation to bid strongly for project funds ...

(Roberts, 1992, 228)

Such bodies were tending to lead the way in the type of consultancy research that led to government policy change, as confirmed by Myers (1991).

The 1990s saw a shake-up in the basis of funding for LIS research, with the British Library Research and Development Department morphing into the British Library Research and Information Centre in 1996, complete with its own consultancy service. This, however, disappeared with the next transmutation into the Library and Information Commission in 1999, which in turn from 2000 was absorbed into Resource. How did these changes affect the research consultancy scene? The effects were large, according to McNicoll and Nankivell (2005) and not far short of huge, according to Dave Nicholas, writing with the advantage of hindsight in 2006. He claimed that: 
If anything, Resource was even more focussed on consultancy than its predecessors... consultancy was replacing research and even the 'research' that was being funded was increasingly being directed, as a consequence of the increase in tendering... or programme-directed or thematic research...

(Nicholas, 2006)

How many research-focussed consultancy organisations were operating or hovering on the periphery of their next contract or project in this period? This number is hard to gauge, largely because of the continuing phenomenon of consultancy research being seen as a staging post to retirement. However, excluding the clutch of university-based research and consultancy centres, the review of LIS research funding carried out for the main funding body at the close of the last decade (Haynes, Streatfield and Cookman, 2000) garnered evidence from representatives of 35 consultancy organisations in the UK (a few of which may not have been active in LIS research at that time). Since such a survey was by its nature confined to the more research-active organisations, this suggests that the predicted growth in research consultancy had occurred.

\section{Still invisible}

Commenting on the first half of the current decade, Nicholas (2007) emphasised the continuing trend as he saw it but also threw light onto why consultancy research tends to be 'invisible':

... with funding bodies like JISC and the DCMS opting ever more for a tenderbased form of research commissioning, information consultancies such as Electronic Publishing Services Ltd. and TFPL continued to make inroads into what was once academic research territory. Because consultancy-based research work tends not to result in peer-reviewed publication this generally resulted in a loss to the UK LIS research literature.

(Nicholas, 2007)

\section{Looking ahead: LIS policy and practice in the next ten years}

If you want to see how the parasite will evolve, look at the host. I'm not at all sure whether this is good biology but it does offer a way of seeing how the research consultancy market might develop. In this case, the hosts are of two kinds, the policy shapers and the practitioners.

How is LIS policy likely to develop in the UK? It is fairly easy to predict that there will be little, if any, expansion in financial and other resources over the next decade and it is a fair guess that information technology will continue to evolve. This evolution is already affecting libraries of all kinds, with an exodus away from books and other traditional resources in favour of digitised resources and einformation and a corresponding move by users towards Google and the Internet (Research Information Network and Consortium of University Research Libraries, 2007). There is also the beginning of a recognition that the traditional library reputation in the areas of assembling balanced collections of print-based resources and helping people to enhance their ability to find and obtain information is likely 
to be eroded by increasingly sophisticated e-searching tools, coupled with yet more e-publications.

What are the short-term research issues in relation to these changes? In schools, there is growing interest in information literacy support for children to equip them to deal with the second age of information. For slightly different reasons, to do with the changing profile of students, other academic institutions are broadening their intake through the Widening Participation agenda as well as shifting attention from traditional full-time undergraduates and support for teaching towards overseas students and part-time provision, including distance learning. Many universities are also seeking a higher research profile. Not surprisingly, academic libraries are responding by following schools and further education libraries into the world of information literacy (Streatfield and Markless, 2007). The traditional user education sessions are beginning to wilt under the pressure of increasing demand for information literacy support and there is a growing move towards blended learning approaches based on a combination of face-to-face and e-learning, focussing increasingly on helping people to develop their skills in the management of information and in systematic evaluation of research evidence.

At the same time, university libraries are looking towards postgraduate and postdoctoral researchers to justify their continued existence, again with a more sophisticated take on information literacy than hitherto (Streatfield, Allen and Wilson, 2008). Since there are few ready answers in all these areas, practitioners are likely to turn to consultants as well as to academic researchers to help them develop workable strategies, possibly using action research approaches that allow the services to respond to problems and to test these responses as they go rather than adopt the traditional academic research approach of investigation followed by reporting and making recommendations.

Other trends which are attracting consultancy research attention include:

- the shift from traditional performance indicators towards engagement with impact evaluation as a means of satisfying the accountability requirements of the new managerialism without fundamentally distorting the services provided, as managerial targets inevitably do (see the research chapter in Markless and Streatfield, 2006);

- approaches to evidence-based LIS work, especially in the health libraries domain (again, often focussing on impact evaluation work but this time driven by a service development agenda). An example of a collaborative approach (by university library teams) to this problem area that adopted an action research mode of working and employed external consultants to help the process was reported in an earlier special issue of this journal (Payne and Conyers, 2005);

- application of various versions of 'knowledge management' in a variety of organisations, as the brave new face of strategic information management or in technology-led applications (notably by TFPL);

- as well as a pious hope that somehow LIS can engage with young people through Web 2.0 (which appears to have evolved largely as a way of getting away from parental and authoritarian influence). 


\section{Looking further ahead}

Some of the major preoccupations for LIS consultants in their research guise are likely to involve a continuation of themes that received substantial attention in the late $20^{\text {th }}$ century, such as:

- continuing interest in how people seek and obtain information (largely an academic research concern so far) and how they can be helped to do so (more of a research consultancy issue);

- exploration of the educational, organisational and social contexts within which people inter-relate with information (one dimension in which academic and consultancy researchers have collaborated - see, for example Bryson, Usherwood and Streatfield, 2002);

- external evaluation of national LIS initiatives (another area of collaboration, such as that between the Centre for the Public Library and Information in Society (University of Sheffield) and Information Management Associates (Streatfield and others, 2007);

- a continuing, but probably declining interest in how information services and systems are designed and managed to enable people to use information and how well these systems perform;

- a staple interest in how people can manage information as a strategic organisational resource (knowledge management and all that).

As we plunge headlong into the $21^{\text {st }}$ century, some other research concerns are likely to engage research consultants as well as academic researchers and, increasingly, in-house researchers:

- a growing interest across the LIS scene in how people engage with information in sense-making and how they can be encouraged to do so more effectively;

- how people can manage information for their own research and practice requirements and (importantly) how they can be encouraged to do so more effectively in a rapidly evolving e-environment;

- whether and how changes in the information landscape (such as the advent of Web 2.0) and in how people engage with the new technologies affect the way in which they think. For example, changes in neurolinguistic 'wiring' through prolonged exposure to e-games playing (Westwell, 2007) or interaction (e.g. Dron and Anderson, forthcoming);

- the effectiveness of various types of intervention (e.g. enhancing access to information; information literacy offerings).

\section{Some (likely) changes in research consultancy}

If these are some of the likely themes for the future, what kinds of demands will they put on future consultancy researchers? In his recent overview of the LIS research scene Peter Brophy (2007) judged that: 
... the environment in 2006 is undoubtedly far more competitive than it was even six years ago and certainly at BLRDD's foundation in 1974. Researchers need to present well thought out proposals which demonstrate a clearly articulated research question, sound methodologies, innovative ideas and a clear understanding of the theoretical basis of their proposed research. They need to be persistent, with a long term view. They need to work in partnership with others who can bring varied skills to the table.

(Brophy, 2007, 19)

In response, we might say that the best LIS research has always embraced all of these requirements, with the exception of working in partnerships. Partnerships across traditional demarcation lines are now beginning to happen, with several consultants being employed alongside, or as part of, LIS research teams and, in some instances leading the work.

What else is likely to change? LIS research ten years down the line is likely to be:

- more complex, encompassing a wider range of research methods and with greater emphasis on engaging practitioners in research through facilitated action research. There are already signs of a plethora of specialist research support software applications emerging and consultancies will seek to gain and maintain a market edge by offering cutting edge products;

- more strategic, with yet more policy-directed commissioning of research and with funder insistence upon provision of workable recommendations geared to national and governmental priorities;

- preoccupied with increased organisational divergence, requiring sharper analysis of organisational problems and with greater convergence of information-based services and systems. There may be a shift away from generic knowledge management (based on formulaic responses to diagnosed problems) towards knowledge management in context (calling for original solutions to unique problems - there is already talk about KM 2.0 which is seen as focusing on individual rather than organisational information management issues);

- focussed on greater organisational convergence. There is likely to be a closing of the ground between the various information-based domains, such as the 'information end' of ICT, knowledge management and LIS management;

- more flexible in executing research contracts, with both short-term and more sustained alliances between academic researchers, research consultants and practitioners. The aim will be to ensure optimum access to requisite skills and expertise through the creation of sophisticated research teams to engage with an increasingly complex and interdisciplinary research environment;

- more international, as multi-national players and organisations in developed and developing countries seek to learn from each others' experience (an example is the current five year project to assess the impact of public access to ICT being undertaken by the Bill and Melinda 
Gates Foundation, the Canadian International Development Research Centre and the Center for Internet Studies, University of Washington, which is already drawing in a range of consultants);

- concerned with yet more difficult research issues, such as achieving a greater understanding of tacit knowledge (especially whether and how the tacit knowledge of experts can be unlocked) and understanding neurolinguistic programming (looking at such issues as whether 'digital natives are being 'rewired' through constant engagement with ICT).

\section{Consultancy researchers of the future}

If any or all of these changes occur, there are huge implications in terms of the changing requirements for the future skills and expertise of all LIS researchers, including consultancy researchers. They are likely to need:

- better inter-personal and diagnostic skills, to enable them to engage more effectively with policy makers, funders and especially with people working and learning in all kinds of organisations;

- more expertise and constant updating in a range of disciplines from ICT applications to metadata, statistical analysis to learning theory, information literacy to information-seeking in context research;

- stronger social science research skills (especially in research interviewing and running structured focus groups, but also in applying these skills to the emerging social space of the Internet);

- other specialist skills (e.g. application of psychometric profiling; using concept mapping to engage with research respondents);

- training and professional development skills and expertise, from facilitation of venting (to allow staff of organisations to express their frustrations about the impact of the exponential growth in accessible information and its consequences, not all of which are benign) through to supporting staff development, organisational development and management of change;

- enhanced impact evaluation skills and expertise, including the facilitation skills needed to support self-evaluation programmes. These will include not only the managerialist expertise required to set and evaluate organisational targets, but also expertise in executing national surveys, gauging the economic impact of services and the ability to explore the impact of information through sophisticated ethnographic studies.

How will consultancy researchers acquire and sustain this range of expertise? There appears to be little or no future for the small independent LIS research teams or individual researchers because the variety of skills and expertise needed and the problem of keeping up-to-date without the access to research libraries and specialist websites that academic researchers take for granted will continue to grow. On the other hand, academic research teams are likely to become bigger and more ponderous in operation, so the way forward does appear to entail more flexible ways of working, including the creation of temporary or longer-term 
multi-disciplinary teams in which LIS research consultants could play a significant part.

On the other hand, all of this speculation may prove as fruitless as most exercises in forecasting, including those conducted by LIS consultancy researchers!

\section{References}

Brophy, P. (2007) Always look on the bright side: LIS research since 2000, Library and Information Research, 31(97), 14-19.

Bryson, J., Usherwood, R.C. and Streatfield, D.R. (2002) Social impact audit for the South West Museums, Libraries and Archives Council. Sheffield: University of Sheffield Centre for Public Library and Information in Society.

Dron, J. and Anderson, T. (forthcoming) How the crowd can teach: Groups, networks and collectives in social software for e-learning. In: Hatzipanagos, S. and Warburton, S. (eds.) Social software and developing community ontologies. Hershey, Pennsylvania: IGI Global.

Haynes, D., Streatfield, D.R. and Cookman, N. (2000) Review of research funding for LIS. Library and Information Commission Research Report 40. London: LIC.

McNicol, S. and Nankivell, C. (2005) The LIS research landscape: a review and prognosis. Birmingham: Centre for Information Research (CIRT), University of Central England.

Markless, S. and Streatfield, D.R. (2006) Evaluating the impact of your library. London: Facet.

Moore, N. (1988) Research. In: Bromley, D.W. and Allott, A.M. (eds.) British librarianship and information work 1981-1985. Volume one: General libraries and the profession. London: Library Association.

Myers, C. (1991) Research policy: a private sector perspective. In: Harris, C. (ed.) Research policy in library and information science. Aldershot: Taylor Graham.

Nicholas, D. (2006) Research. In: Bowman, J.H. (ed.) British librarianship and information work 1991-2000. Aldershot: Ashgate.

Nicholas, D. (2007) Research. In: Bowman, J.H. (ed.) British librarianship and information work 2001-2005. Aldershot: Ashgate.

Payne, P. and Conyers, A. (2005) Measuring the impact of Higher Education libraries: the LIRG/SCONUL Impact Implementation Initiative. In: Library and Information Research News, 29(91), 3-9. The whole of this special issue is devoted to the Impact Implementation Programme.

Research Information Network and the Consortium of Research Libraries (2007)

Researchers' use of academic libraries and their services. London: RIN and CURL. URL: http://www.rin.ac.uk/files/libraries-report-2007.pdf [accessed 26.04.08]. 
Roberts, S. (1992) Research. In: Bromley, D.W. and Allott, A.M. (eds.) British librarianship and information work 1988-1990. Volume one: General libraries and the profession. London: Library Association.

Streatfield, D.R., Allen, D. and Wilson, T.D. (2008) Training of researchers in research information methodologies and tool: report commissioned by the Research Information Network. Leeds: AIMTech Research Group, Leeds University Business School and Information Management Associates.

Streatfield, D.R. and Markless, S. (2007) Information literacy. In: Bowman, J.H. (ed.) British librarianship and information work 2001-2005. Aldershot: Ashgate.

Streatfield, D.R., Wilson, K., Corrall, S. and Usherwood, R.C. (2007) Evaluation of leading modern public libraries [by] Information Management Associates and the Centre for the Public Library and Information in Society. London: Museums, Libraries and Archives Council and the Society for Chief Librarians.

Westwell, M. (2007) Bending minds: How technology can change the way we think. Paper presented at the Information: Interactions and Impact Conference, Aberdeen Business School, $26^{\text {th }}$ June 2007.

Yelland, M. (1977) Research in library and information science. In: Whatley, H. A. (ed.) British librarianship and information science 1971-1975. London: Library Association.

Yelland, M. (1982) Research. In: Taylor, L.J. (ed.) British librarianship and information work 1976-1980. London: Library Association. 